\title{
Korelasi Kemampuan Memahami Ciri Pantun dan Kemampuan Menentukan Jenis Pantun dengan Kemampuan Menulis Pantun Siswa Kelas VIII SMP Negeri I Pagaralam
}

\author{
Oleh \\ Chairil Amar \\ Guru SMPN I Pagaralam Sumatra Selatan \\ Email:amarchairil@yahoo.com
}

\begin{abstract}
This study wants to answer about the correlation between the ability to understand the features and capabilities to determine what kind of rhymes with the ability to write rhymes of students in class VIII at SMP Negeri 1 Pagaralam. The purpose of this study was to describe the correlation between the ability to understand the features and capabilities to determine what kind of rhymes with the ability to write rhymes of students in class VIII at SMP Negeri 1 Pagaralam. This study used a descriptive and correlation method. The results of data analysis research concluded, that there is a significant correlation of the ability to understand the characteristics and capabilities to determine what kind of rhymes with the ability to write rhymes of students in class VIII SMP Negeri 1 Pagaralam. The hypothesis shown that there is a significant correlation between the understanding of the characteristics and capabilities to determine what kind of rhymes with the ability to write rhymes of students in class VIII at SMP Negeri 1 Pagaralam that proven true.
\end{abstract}

Keywords: correlation, the characteristics of rhyme, rhyme types, writing rhymes.

\section{Pendahuluan}

Sastra berkaitan erat dengan aspek kehidupan manusia dan alam. Setiap karya sastra selalu menghadirkan sesuatu yang bila dihayati benar-benar dapat menambah pengetahuan, penghayatan, dan pengalaman bagi seseorang (Rahmanto, 2003:17). Menurut Tarigan (2004:3), Sastra adalah pembayangan atau pelukisan kehidupan dan pemikiran imajinatif yang dikemukakan melalui bahasa. Sastra meliputi kehidupan manusia, yaitu kehidupan dengan segala perasaan, pikiran, dan wawasannya.

Puisi, termasuk pantun merupakan salah satu hasil cipta karya sastra. Untuk menghasilkan puisi digunakan bahasa. Tanpa bahasa, puisi tidak mungkin tercipta. Sayuti (2007:56) mengemukakan, bahasa dalam puisi digunakan oleh penyair untuk mencetuskan perasaan, pikiran, gagasan, atau nilai-nilai yang sangat berguna dan berharga bagi kehidupan manusia. Bahasa dalam puisi berfungsi sebagai pendukung arti dan pengemban rasa. Puisi bermanfaat bagi manusia jika pembaca mampu memahami isi atau makna yang terkandung dalam puisi yang dibacanya. Jika seseorang memahami makna kata-kata atau bahasa yang digunakan oleh penyair dalam puisi, maka semakin mudahlah ia memahami isi atau makna puisi 
tersebut. Menurut Tarigan (2004:138), dengan memahami makna puisi, pembaca akan memperoleh manfaat, baik dari segi hiburan maupun manfaat dari segi nilai-nilai yang berguna dalam kehidupan manusia, seperti nilai moral, sosial budaya, agama, pendidikan.

\section{Dalam Depdiknas}

$(2006: 50)$ dinyatakan bahwa pantun sebagai puisi rakyat merupakan salah satu sastra lisan yang berhubungan dengan tradisi atau adat-istiadat dan budaya suatu daerah yang dapat menunjang serta menambah perkembangan sastra Indonesia. Namun, sangat disayangkan puisi-puisi rakyat tersebut akhir-akhir ini sudah agak jarang dituturkan, khususnya oleh generasi muda. Hal ini disebabkan oleh kurangnya minat generasi muda daerah tersebut untuk mempelajari dan menggunakannya.

Dalam Standar Isi Kurikulum 2013, Bahasa Indonesia, Sekolah Menengah Pertama (SMP) terdapat kompetensi dasar menulis dengan materi pokok membuat atau menulis pantun. Hal tersebut membuktikan bahwa siswa perlu memiliki kemampuan membuat atau menulis pantun. Tujuan pembelajaran pantun di sekolah adalah agar pantun sebagai hasil puisi asli nusantara dapat dilestarikan dan menumbuhkan apresiasi siswa terhadap pantun.
Sehubungan dengan pentingnya pelestarian pantun sebagai salah satu puisi asli hasil karya sastra nusantara dan kekurangmampuan siswa menulis pantun di beberapa SMP di Pagaralam karena kurangnya minat siswa mempelajari pantun dan adanya anggapan bahwa pantun itu tidak perlu dipelajari karena sudah jarang digunakan membuat penulis tertarik meneliti kemampuan siswa menentukan ciri-ciri, jenis-jenis, dan kemampuan siswa menulis atau membuat pantun, khususnya di SMP Negeri 1 Pagaralam.

Penulis menetapkan objek atau tempat penelitian SMP Negeri 1 Pagaralam berdasarkan alasan: (1) sekolah tersebut berstatus SMP negeri dan ber-kualitas baik, yang terbukti melalui per-sentase kelulusan siswa setiap tahunnya mencapai rata-rata 89,8\% ke atas, (2) SMP Negeri 1 Pagaralam sudah cukup dikenal oleh masyarakat di sekitar Kota Pagaralam; (3) sebagai SMP berstatus negeri, sekolah tersebut banyak diminati oleh masyarakat sehingga SMP Negeri 1 Pagaralam memiliki siswa yang cukup banyak; (4) siswa kelas VIII SMP Negeri 1 Pagaralam sudah mempelajari materi pembelajaran tentang pantun yaitu di kelas VIII semester 1, namun berdasarkan observasi ternyata masih banyak siswa yang mengalami kesulitan dalam mema-hami ciriciri pantun dan menulis pantun. Selain itu, 
menurut informasi dari Kepala SMP Negeri 1 Pagaralam dan guru Bahasa Indonesia di sekolah tersebut, pe-nelitian mengenai hubungan pemahaman ciri-ciri pantun dan kemampuan menentukan jenis-jenis pantun dengan kemam-puan menulis pantun di kelas VIII SMP Negeri 1 Pagaralam belum pernah dila-kukan.

Berdasarkan latar belakang yang telah dikemukakan, masalah yang teridentifikasi dalam penelitian ini adalah perlu-nya melakukan penelitian tentang korelasi antara pemahaman ciri-ciri pantun dan kemampuan menentukan jenis pantun de-ngan kemampuan menulis pantun pada siswa kelas VIII SMP Negeri 1 Pagaralam. Identifikasi masalah penelitian ini adalah sebagai berikut.

1. Bagaimana korelasi antara kemampuan memahami ciri-ciri pantun dengan kemampuan menulis pantun pada siswa kelas VIII SMP Negeri 1 Pagaralam?

2. Bagaimana korelasi antara kemampuan menentukan jenis pantun dengan kemampuan menulis pantun siswa kelas VIII SMP Negeri 1 Pagaralam? 3. Bagaimana korelasi kemampuan memahami ciri-ciri pantun dan kemampuan menentukan jenis pantun dengan kemampuan menulis pantun siswa kelas VIII SMP Negeri 1 Pagaralam?

Pembatasan masalah penelitian ini adalah bagaimana korelasi antara pemahaman ciri-ciri pantun dan kemampuan menentukan jenis pantun dengan kemampuan menulis pantun, khususnya pantun biasa, karmina atau pantun kilat, dan talibun.pada siswa kelas VIII SMP Negeri 1 Pagaralam.

Rumusan masalah penelitian ini adalah sebagai berikut.

1. Apakah terdapat korelasi yang signifikan antara kemampuan memahami ciri-ciri pantun dengan kemampuan menulis pantun pada siswa kelas VIII SMP Negeri 1 Pagaralam?

2. Apakah terdapat korelasi yang signifikan antara kemampuan menentukan jenis pantun dengan kemampuan menulis pantun pada siswa kelas VIII SMP Negeri 1 Pagaralam?

3. Apakah terdapat korelasi yang signifikan antara kemampuan memahami ciri-ciri pantun dan kemampuan menentukan jenis pantun dengan kemampuan menulis pantun siswa kelas VIII SMP Negeri 1 Pagaralam?

Hasil penelitian ini diharapkan bermanfaat, baik secara teoretis maupun secara praktis. Secara teoretis, hasil penelitian ini diharapkan dapat digunakan untuk memperkaya literatur tentang pantun, khususnya di perpustakaan sekolah. Secara praktis, hasil penelitian ini diha-rapkan bermanfaat bagi siswa, guru, dan sekolah. Bagi siswa, hasil penelitian ini diharapkan 
dapat memotivasi minat siswa untuk mempelajari ciri-ciri pantun, jenis pantun, dan menulis pantun; bagi guru, hasil penelitian ini diharapkan dapat dijadikan masukan tentang korelasi pemahaman ciriciri pantun dan kemampuan menentukan jenis pantun dengan kemampuan menulis pantun; dan bagi sekolah, hasil penelitian ini diharapkan dapat dijadikan bahan masukan mengenai hasil pembelajaran Bahasa Indonesia, khususnya pada pembelajaran pantun.

\section{Kajian Teoretis}

\section{A. Pengertian Pantun}

Sudaryat (2006:170) mengemukakan bahwa pantun merupakan hasil karya sastra puisi lama yang berupa puisi asli yang bentuknya terdiri atas empat baris sebait dengan rumus sajak a-b-a-b. Setiap baris biasanya terdiri atas 8-12 suku kata. Baris pertama dan kedua berupa sam-piran, sedang baris ketiga dan keempat berupa isi. Menurut Suroso (2008:74), pantun merupakan sanjak yang terdiri atas 4 baris sebait. Pantun menggunakan rumus persajakan a-b-a-b serta memiliki sampiran dan isi. Ambary (2005:24) menyatakan bahwa pantun adalah hasil cipta sastra berupa sajak yang tiap bait terdiri atas empat baris, tiap baris terdiri atas 8 sampai 12 suku kata, bersajak sengkelang, berumus $a-b-a-b$, dua baris pertama merupakan sampiran, sedangkan isinya terdapat pada dua baris terakhir.

Menurut Moeliono (2002:728), pantun adalah bentuk puisi asli Indonesia (Melayu), tiap bait (kuplet) biasanya terdiri atas empat atau lima kata, bersajak (a-b-a-b), tiap larik terdiri atas empat kata, baris pertama dan kedua sampiran dan baris ketiga dan keempat merupakan isi. Utami (2013:8) menyatakan, pantun adalah salah satu hasil karya sastra jenis puisi lama yang sangat dikenal dalam bahasa nusantara. Dalam bahasa Sunda misalnya, pantun dikenal sebagai paparikan dan dalam bahasa Jawa dikenal sebagai parikan.

Pantun merupakan salah satu jenis puisi lama yang sangat luas dikenal dalam bahasa-bahasa Nusantara. Dalam bahasa Jawa, misalnya, dikenal sebagai parikan, dalam bahasa Sunda dikenal sebagai paparikan, dan dalam bahasa Batak dike-nal sebagai umpasa (uppasa). Lazimnya pantun terdiri atas empat larik (atau empat baris bila dituliskan), bersajak akhir dengan pola a-b-ab dan a-a-a-a (tidak boleh a-a-b-b, atau a-b-ba). Pantun pada mulanya merupakan sastra lisan namun sekarang dijumpai juga pantun yang tertulis. Semua bentuk pantun terdiri atas dua bagian: sampiran dan isi. Sampiran adalah dua baris pertama, kerap kali berkaitan dengan alam (mencirikan budaya agraris masyarakat pendukungnya), dan 
biasanya tak punya hubungan dengan bagian kedua yang menyampaikan maksud selain untuk mengantarkan rima/sajak. Dua baris terakhir merupakan isi, yang merupakan tujuan dari pantun tersebut (Wikipedia Bahasa Indonesia, Ensiklopedia Bebas, 2012).

Berdasarkan pendapat di atas dapat disimpulkan bahwa pantun adalah bentuk puisi lama yang berupa puisi asli Indonesia (Melayu) yang terdiri atas empat sebait, menggunakan sajak sengkelang dengan rumus persajakan a-b-a-b, umumnya terdiri atas empat kata sebait, serta memiliki sampiran dan isi. Lazimnya pantun terdiri atas empat larik (atau empat baris bila dituliskan), bersajak akhir dengan pola a-b-ab. Pantun pada mulanya merupakan sastra lisan namun sekarang sudah banyak pantun yang ditulis.

\section{B. Ciri-Ciri Pantun}

Sudaryat (2006:170) mengemukan ciri-ciri pantun, yaitu: (a) pantun adalah puisi asli Indonesia, (b) terdiri atas empat baris sebait, (c) setiap baris biasanya terdiri atas 8-12 suku kata, d) setiap baris (larik) terdiri atas tiga sampai lima kata, (e) rumus sajak akhir a-b-a-b, dan (f) baris pertama dan kedua berupa sampiran, sedangkan baris ketiga dan keempat berupa isi pantun. Suroso (2008:74) menyatakan bahwa ciri-ciri pantun adalah: (a) pantun merupakan puisi asli Indonesia tersebar di seluruh daerah dan dikenal oleh masyarakat setiap daerah di Indo-nesia, (b) banyak menggunakan bahasa daerah dan bahasa Melayu, (c) setiap bait dapat terdiri atas 4 baris atau 2 baris, dan ada yang 6,8 , atau 10 baris, (d) setiap baris terdiri atas 8 sampai 12 suku kata dan umumnya 10 suku kata, (e) setengah jumlah barisnya merupakan sampiran, sedangkan setengah jumlah baris berikut-nya merupakan isi, (f) pantun bersajak silang dengan rumus a-b-a-b. Menurut Utami (2013:13), pantun memiliki ciri-ciri, yaitu: (1) setiap bait terdiri atas empat larik (baris). Setiap suku kata setiap larik sama atau hampir sama, biasanya terdiri atas delapan sampai dua belas suku kata), (3) bersajak a-b//a-b, (4) larik (baris) pertama dan kedua merupakan sampiran dan larik ketiga dan keempat merupakan isi (pada pantun biasa yang terdiri atas empar larik sebait).

Berdasarkan pendapat-pendapat tersebut, dapat disimpulkan bahwa pantun memiliki ciri-ciri, yaitu: (a) pantun adalah puisi asli Indonesia yang terdapat di seluruh daerah nusantara serta meng-gunakan bahasa daerah dan Melayu, (b) setiap bait terdiri atas empat baris, atau dua baris, atau 6,8 , atau 10 baris (selalu genap), (c) setiap baris (larik) terdiri atas tiga sampai lima kata, (d) setiap baris terdiri atas 8 sampai 12 suku kata, (e) 
bersajak silang dengan rumus $a-b-a-b$, dan (f) setengah jumlah baris awal merupakan sampiran dan setengah jumlah larik berikutnya berupa isi.

\section{Struktur Pantun}

Utami (2013:14) mengemukakan bahwa pantun memiliki struktur, yaitu dibentuk atas dua bagian yang terdiri atas sampiran dan isi. Sampiran berfungsi untuk menyiapkan rima dan irama agar mempermudah pendengar memahami pantun. Meskipun pada umumnya sampiran tidak memiliki hubungan dengan isi, tetapi terkadang sampiran memberi bayangan terhadap isi pantun. Sedangkan, isi merupakan bagian inti pantun yang berisi maksud atau pikiran pembuat pantun.

Menurut Mihardja (2012:12), struktur pantun terdiri atas sampiran dan isi. Sampiran terutama menyiapkan rima dan irama untuk mempermudah pendengar memahami isi pantun. Sampiran pada pantun umumnya tidak berhubungan dengan isi, tetapi dapat sebagai bayangan isi. Hal ini dapat dipahami karena pantun pada zaman dahulu merupakan sastra lisan. Isi merupakan bagian ini yang mengungkapkan pikiran atau maksud pembuat pantun.

Jadi dapat disimpulkan bahwa pantun memiliki struktur yang terdiri atas sampiran dan isi. Sampiran berfungsi menyiapkan rima dan irama yang dapat membantu pendengar memahami isi pantun. Pada umumnya sampiran tidak memiliki hubungan dengan isi, tetapi terkadang sampiran dapat memberi bayangan terhadap isi pantun. Isi merupakan bagian inti pantun yang berisi maksud atau pikiran pembuat pantun.

\section{Jenis Pantun}

Pantun terdiri atas beberapa macam atau jenis, baik ditinjau dari segi jumlah barisnya setiap bait maupun berdasarkan isinya. Suroso (2008:75) mengemukakan, berdasarkan jumlah barisnya, pantun ada tiga macam, yaitu pantun kilat (karmina), pantun biasa, dan talibun. Berdasarkan isinya, pantun terdiri atas pantun kanak-kanak, pantun muda-mudi, dan pantun orang tua. Menurut Sudaryat (2006:171), pantun dapat dibedakan macamnya berdasarkan jumlah barisnya setiap bait dan berdasarkan isinya. Berdasarkan jumlah barisnya setiap bait ada pantun kilat atau karmina, pantun biasa, dan talibun. Berdasarkan isinya, ada pantun anakanak, pantun muda-mudi, dan pantun orang tua.

Ambary (2005:25) menyatakan bahwa pantun berdasarkan jumlah baris dalam setiap bait terdiri atas jenis karmina (pantun kilat), pantun biasa, dan talibun. Melihat isinya, ada pantun kanak-kanak, pantun muda, dan pantun orang tua. 
Berdasarkan pendapat-pendapat di atas, dapat disimpulkan bahwa pantun ada beberapa macam, ditinjau dari segi jumlah barisnya dalam setiap bait dan berdasarkan isinya. Berdasarkan jumlah barisnya, pantun ada tiga macam, yaitu pantun kilat (karmina), pantun biasa, dan talibun. Berdasarkan isinya, pantun terdiri atas pantun kanakkanak, pantun muda-mudi, dan pantun orang tua.

\section{E. Jenis Pantun Berdasarkan Jumlah}

\section{Baris Setiap Bait}

\section{Pantun Kilat atau Karmina}

Ambary (2005:28) mengemukakan, pantun kilat (karmina) adalah jenis pantun yang singkat, hanya terdiri atas dua baris sebait. Karmina memiliki ciri-ciri, yaitu terdiri atas dua baris sebait, baris pertama merupakan sampiran dan baris kedua berupa isi, dan bersajak a-a (sajak rata). Menurut Djajadisastra (2006:37), karmina adalah jenis pantun kilat yang terdiri atas dua baris sebait, bersajak a-a, dan baris pertama berupa sampiran, baris kedua berupa isi.

Suroso (1998:18) menyatakan, pantun kilat adalah bentuk pantun yang terdiri atas dua baris sebait, bersajak rata dengan rumus a-a, dan baris pertama berupa sampiran dan baris kedua berupa isi. Menurut Utami (2013:12), karmina adalah pantun dua seuntai atau sebait terdiri atas dua larik (pantun kilat), baris pertama sebagai sampiran dan baris kedua sebagai isi, dengan rumus persajakan a-a, isinya berupa sindiran, nasihat, atau pernyataan ungkapan hati/pikitan.

Berdasarkan pendapat-pendapat di atas, dapat disimpulkan bahwa karmina adalah jenis pantun kilat yang terdiri atas dua baris sebait, bersjak a-a, dan baris pertama berupa sampiran, sedangkan baris kedua berupa isi.

\section{Pantun Biasa}

Ambary (2005:24) mengatakan, pantun biasa ialah pantun yang umum dan terdiri atas empat baris sebait, bersajak a-b-ab, baris pertama dan kedua merupakan sampiran, baris ketiga dan keempat berupa isi, setiap baris terdiri atas 8-12 suku kata, dan setiap baris terdiri atas 4 atau kata. Menurut Sumardjo (200:90), pantun biasa adalah jenis pantun terdiri atas empat baris sebait, bersajak a-b-a-b, baris pertama dan kedua sampiran dan baris ketiga dan keempat berupa isi. Sudaryat (2006:171) menyatakan bahwa pantun biasa adalah jenis pantun yang terdiri atas empat baris sebait, bersajak a-b-ab, setiap baris ter-diri atas 8-12 suku kata, baris pertama dan kedua berupa sampiran, sedangkan baris ketiga dan keempat berupa isi. 
Berdasarkan pendapat-pendapat di atas, dapat disimpulkan bahwa pantun biasa adalah jenis pantun yang umum dan terdiri atas empat baris sebait, bersajak silang dengan rumus $a-b-a-b$, baris per-tama dan kedua merupakan sampiran, sedangkan baris ketiga dan keempat me-rupakan isi, setiap baris terdiri atas 8 sampai 12 suku ka-ta, dan setiap baris terdiri atas 4 atau kata.

\section{Talibun}

Sudaryat (2006:172) menyatakan, talibun adalah bentuk pantun yang terdiri atas enam atau delapan baris se-bait, setengah jumlah baris merupakan sampiran dan setengah jumlah baris ber-ikutnya berupa isi, memiliki rumus per-sajakan abc//abc atau $\mathrm{abcd} / / \mathrm{abcd}$.

Menurut Utami (2013:9), talibun adalah bentuk puisi lama yang termasuk jenis pantun, jumlah barisnya antara 6 sampai 20 baris (selalu genap), talibun memiliki sampiran dan isi, yaitu setengah dari jumlah baris pertama dari keseluruhan sebagai sampiran dan setengah jumlah baris berikutnya sebagai isi, persajakannya abcabc atau abcd-abcd atau aab-aab atau aabbaabb atau abcde-abcde dan seterusnya. Talibun biasanya berisi tema mengisahkan kebesaran atau kehebatan seseorang atau suatu tempat, mengisahkan keajaiban sesuatu benda atau peristiwa, mengisahkan kehebatan atau kecantikan seseorang, atau mengisahkan kelakuan dan sikap manusia.

Berdasarkan pendapat-pendapat di atas, dapat disimpulkan bahwa talibun adalah adalah jenis pantun yang terdiri atas enam atau delapan baris sebait, bersajak abc//abc untuk enam baris sebait dan bersajak abcd//abcd untuk yang delapan baris sebait, empat pertama merupakan sampiran, sedangkan empat baris berikutnya merupakan isi.

\section{F. Jenis Pantun Berdasarkan Isinya}

Sudaryat (2006:171) mengemukakan, berdasarkan isinya pantun ada beberapa macam, yaitu pantun kanak-kanak, pantun muda-mudi, dan pantun orang tua. Menurut Suroso (2008:19), pantun berdasarkan isinya ada tiga macam, yaitu pantun anak-anak, pantun muda-mudi, dan pantun orang tua. Djajadisastra (2006:38) menyatakan bahwa dilihat dari isinya, pantun dapat dibedakan menjadi tiga macam, yaitu pantun kanakkanak, pantun muda-mudi, dan pantun orang tua. Pantun kanak-kanak dibagi lagi menjadi pantun bersuka cita dan pantun berduka cita. Pantun muda-mudi terdiri atas pantun nasib atau pantun dagang, pantun perhubungan, pantun perkenalan, pantun berkasih-kasihan, pantun perceraian, pantun beriba hati, pantun jenaka, dan pantun teka-teki. Pantun orang 
tua terdiri atas pantun adat, pantun agama, pantun nasihat.

Berdasarkan pendapat-pendapat di atas, dapat disimpulkan bahwa pantun berdasarkan isinya ada tiga macam, yaitu pantun kanak-kanak, pantun muda-mudi, dan pantun orang tua. Pantun kanak-kanak dibagi lagi menjadi pantun bersuka cita dan pantun berduka cita. Pantun muda-mudi terdiri atas pantun nasib atau pantun dagang, pantun perhubungan, pantun perkenalan, pantun berkasih-kasihan, pantun perceraian, pantun beriba hati, pantun jenaka, dan pantun tekateki. Pantun orang tua terdiri atas pantun adat, pantun agama, pantun nasihat.

\section{Pantun Kanak-Kanak}

Pantun kanak-kanak adalah jenis pantun yang biasanya digunakan oleh anakanak dan sesuai dengan dunia kanak-kanak. Pantun kanak-kanak ada tiga macam, yaitu pantun berdukacita, pantun bersukacita, dan pantun nasihat kanak-kanak (Suroso, 2008:80). Menurut Ambary (2005:24), pantun kanak-kanak adalah jenis pantun yang sesuai dengan dunia kanak-kanak dan biasa digunakan untuk mengungkapkan perasaan kanak-kanak. Pantun kanak-kanak terdiri atas pantun berdukacita, pantun bersukacita, dan pantun nasihat. Menurut Utami (2013:61), pantun anak-anak adalah jenis pantun yang lazimnya ditujukan untuk anak-anak dan berisi kata-kata yang layak ditujukan atau dipakai oleh anak-anak. Pantun anak-anak ada yang bersisi pantun sukacita, pantun berdukacita, dan pantun nasihat.

Berdasarkan pendapat-pendapat di atas, dapat disimpulkan bahwa pantun kanakkanak adalah pantun yang sesuai dengan dunia anak-anak dan biasa digunakan untuk mengungkapkan perasaan kanak-kanak. Pantun kanak-kanak terdiri atas pantun berdukacita dan pantun bersukacita.

\section{Pantun Muda-Mudi}

Pantun muda-mudi adalah jenis pantun yang biasanya digunakan oleh para muda-mudi yang terdapat dalam masyarakat. Pantun muda-mudi ini berisi banyak hal, mulai dari pantun yang berisi perkenalan, kejenakaan, dan teka-teki. Hal ini dikemukakan oleh Suroso (2008:21), yaitu bahwa pantun muda-mudi adalah jenis pantun yang biasa ditemukan dan digunakan oleh para pemuda dan pemudi. Sesuai dengan tingkat perkembangan jiwanya, pantun muda-mudi banyak berisi masalah kehidupan remaja, seperti pantun perkenalan, pantun percintaan, pantun berkasih-kasihan, pantun perceraian (putus cinta), pantun jenaka, dan pantun teka-teki. 


\section{Pantun Orangtua}

Pantun orangtua adalah jenis pantun yang biasanya digunakan oleh para orangtua, misalnya dalam acara-acara adat, saat memberikan petuah atau nasihat, atau saat memberikan ajaran agama (Suroso, 2008:82). Menurut Sudaryat (2006:170), pantun orangtua adalah jenis pantun yang biasa digunakan oleh para orangtua, baik yang berisi nasihat, pantun berisi ajaran agama, maupun pantun yang biasanya dipakai saat upacara-upacara adat. Sesuai dengan isi dan tujuannya, pantun orangtua terdiri atas pantun nasihat, pantun adat, dan pantun agama.

\section{G. Makna Pantun}

Utami (2013:16) mengemukakan bahwa pantun memiliki bermacam-macam makna, yaitu makna ungkapan atau curahan perasaan, makna nasihat, makna pengajaran, makna hiburan, makna budaya, makna religi, makna bermain tebak-tebakan, dan lain-lain. Menurut Mihardja (2012:12), makna pantun ditentukan oleh isi. Berdasarkan isinya, pantun memiliki bermacam-macam makna sesuai dengan tujuannya. Misalnya, pantun bermakna nasihat, makna pengajaran, ungkapan perasaan hati, makna menghibur, makna keagamaan atau religi, makna budaya, makna mengajak untuk berpikir, atau makna lelucon. Menurut Suroso (2008:85), pantun memiliki makna yang bermacam-macam sesuai dengan isi dan jenis pantun. Makna pantun, misalnya berisi makna keagamaan atau religi, makna budaya, bermakna nasihat, makna pengajaran, makna mengajak untuk berpikir (teka-teki), makna lelucon, ungkapan perasaan hati, atau makna menghibur.

Berdasarkan pendapat-pendapat di atas, dapat disimpulkan bahwa pantun memiliki bermacam-macam makna sesuai dengan isi dan tujuan pantun. Makna pantun, misalnya makna religi, makna budaya, makna nasihat, makna pengajaran, makna mengajak untuk berpikir (teka-teki), makna lelucon, ungkapan perasaan hati, atau makna menghibur.

\section{H. Cara Menulis Pantun}

Sugiarto

(2013:8--14)

mengemukakan cara menulis pantun agar dapat menulis pantun secara benar diperlukan langkah-langkah sebagai berikut.

1) Harus terlebih dahulu mengetahui ciri-ciri pantun, yaitu terdiri atas empat baris sebait, setiap baris biasanya ter-diri atas 8-12 suku kata, setiap baris (larik) terdiri atas empat sampai lima kata, rumus sajak akhir a-b-a-b, dan baris pertama dan kedua berupa sampiran, sedangkan baris ketiga dan keempat berupa isi pantun. 
2) Menentukan tema sesuai dengan jenis pantun yang akan ditulis, yaitu pantun anak-anak, pantun remaja atau dewasa, dan pantun orang tua.

3) Mengumpulkan kosakata, yaitu kosa-kata yang akan digunakan sesuai dengan tema pantun yang akan ditulis.

4) Teknik penulisan, dengan langkahlangkah sebagai berikut.

(a) Cari kata terakhir untuk isi (baris ke-3 dan ke-4) yang sesuai dengan tema.

(b) Membuat kalimat dengan kata pada baris ke-3 dan ke-4 yang terdiri atas 8--12 suku kata.

(c) Cari kata terakhir untuk sampiran (baris ke-1 dan ke-2) yang sesuai dengan persajakan pantun, yaitu sesuai dengan bunyi fonem suku kata akhir baris ke-3 (-lok) dan ke-4 (jar) sehingga bersajak ab-ab.

(d) Membuat kalimat dengan kata pa-da baris ke-1 dan ke-2 yang ter-diri atas 8--12 suku kata.

(e) Memeriksa kembali pantun yang telah dibuat, yaitu: (1) sudahkah memenuhi syarat sebagai pantun?, (2) sudahkah setiap bait terdiri atas empat baris (larik)?, (3) sudahkah setiap larik terdiri atas 8--12 suku kata?, (4) sudahkah bersajak ab-ab?, (5) sudahkah me-miliki sampiran?, dan (6) sudahkah memiliki isi?

\section{Kerangka Berpikir}

Kerangka berpikir digunakan dalam penelitian dengan dua variabel atau lebih. Kerangka berpikir merupakan model konseptual tentang bagaimana teori berhubungan dengan berbagai faktor yang telah diidentifikasi yang berfungsi menjelaskan secara teoretis pertautan antarvariabel independen dan dependen yang akan diteliti. Sebelum membuat hipotesis, kerangka berpikir perlu dikemukakan terlebih dahulu sehingga hipotesis menjadi lebih jelas. (Sugiyono, 2012:60).

Berdasarkan pendapat, dapat disimpulkan bahwa kerangka berpikir digunakan dalam penelitian dengan dua variabel atau lebih. Kerangka berpikir merupakan model konseptual tentang bagaimana teori berhubungan dengan berbagai faktor yang telah diidentifikasi yang berfungsi menjelaskan secara teoretis pertautan antarvariabel independen dan dependen yang akan diteliti.

\section{J. Hipotesis Penelitian dan Kriteria}

\section{Pengujian Hipotesis}

\section{Hipotesis Penelitian}

Kasmadi (2013:93) mengemukakan, hipotesis dalam penelitian adalah hubungan yang dapat diartikan pernyataan dugaan adanya hubungan antarvariabel dalam sampel. Penulis mengemukakan hipotesis 
sebagai hipotesis alternatif $\left(\mathrm{H}_{\mathrm{a}}\right)$, yaitu, ada korelasi yang signifikan antara pemahaman ciri-ciri pantun dan kemampuan menentukan jenisi pantun dengan kemampuan menulis pantun pada siswa kelas VIII SMP Negeri 1 Pagaralam.

\section{Kriteria Pengujian Hipotesis}

Kriteria pengujian hipotesis penelitian ini ditetapkan sebagai berikut.

1) Ho: Tidak ada korelasi yang signifikan antara pemahaman ciri-ciri pantun dan kemampuan menentukan jenis pantun dengan kemampuan menulis pantun siswa kelas VIII SMP Negeri 1 Pagaralam.

2) Ha: Ada korelasi yang signifikan an-tara pemahaman ciri-ciri pantun dan kemampuan menentukan jenis pantun dengan kemampuan menulis pantun siswa kelas VIII SMP Negeri 1 Pagaralam.

Tolak Ho, jika $\underline{r}_{\text {hit. }} \geq \underline{\mathrm{r}}$ tabel, untuk taraf signifikan 5\% dan terima Ho untuk harga lainnya (Sudijono, 2006:169).

\section{Metodologi Penelitian}

\section{A. Tujuan Penelitian}

Tujuan penelitian ini adalah untuk mengetahui dan mendeskripsikan:

1) ada atau tidaknya korelasi yang signifikan antara kemampuan memahami ciri-ciri pantun dengan kemampuan menulis pantun pada siswa kelas VIII SMP Negeri 1 Pagaralam,
2) ada atau tidaknya korelasi yang signifikan antara kemampuan menentukan jenis pantun dengan kemampuan menulis pantun pada siswa kelas VIII SMP Negeri 1 Pagaralam.

3) kemampuan memahami ciri-ciri pantun, kemampuan menentukan jenis pantun, dan kemampuan menulis pantun siswa kelas VIII SMP Negeri 1 Pagaralam; dan

4) ada atau tidaknya korelasi yang signifikan antara kemampuan memahami ciri-ciri pantun dan kemampuan menentukan jenis pantun dengan kemampuan menulis pantun pada siswa kelas VIII SMP Negeri 1 Pagaralam.

\section{B. Variabel Penelitian}

Sugiyono (2010:60) menyatakan, variabel penelitian adalah segala sesuatu yang berbentuk apa saja yang ditetapkan oleh peneliti untuk dipelajari sehingga diperoleh informasi tentang hal tersebut, kemudian ditarik kesimpulannya. Menurut Arikunto (2002:96), variabel adalah objek penelitian atau apa yang menjadi titik perhatian dalam suatu penelitian.

Berdasarkan pengertian di atas, maka penelitian ini terdiri atas variabel bebas dan variabel terikat. Kemampuan memahami ciriciri pantun $\left(\mathrm{X}_{1}\right)$ dan kemampuan menentukan jenis-jenis pantun $\left(\mathrm{X}_{2}\right)$ sebagai variabel bebas, sedangkan kemampuan menulis 
pantun sebagai vari-abel terikat (Y). Variabel bebas dan varia-bel terikat dihubungkan untuk mengethui ada tidaknya korelasi yang signifikan antara kemampuan memahami ciri-ciri pantun dan menentukan jenis-jenis pantun dengan kemampuan menulis pantun.

\section{Populasi dan Sampel Penelitian}

\section{Populasi Penelitian}

Sugiyono (2010:117) menyatakan, populasi adalah wilayah generalisasi yang terdiri atas objek dan subjek yang memiliki kuantitas dan karaklteristik ter-tentu yang ditetapkan oleh peneliti untuk dipelajari dan kemudian ditarik kesim-pulannya.

Berdasarkan pengertian di atas, maka populasi dalam penelitian ini adalah seluruh siswa kelas VIII SMP Negeri 1 Pagaralam tahun ajaran 2014/2015 yang berjumlah 121 orang, terdiri atas 58 laki-laki dan 63 perempuan.

\section{Sampel Penelitian}

Kasmadi (2013:66) mengemukakan, populasi adalah sebagian dari jumlah dan karakteristik yang dimiliki oleh populasi. Sampel dianggap sebagai sumber data untuk mendukung penelitian. Menurut Sogiyono (2010:118), sampel adalah sebagian dari populasi. Bila populasi besar dan peneliti tidak mungkin meneliti semua populasi, misalnya karena keterbatasan dana, tenaga, dan waktu, maka peneliti dapat menggunakan sampel yang diambil dari populasi.

Dari tiga kelas, penulis menetapkan satu kelas sebagai sampel penelitian yang diambil secara random (acak). Untuk memperoleh sampel random, maka pengambilan sampel penelitian ini dilakukan dengan cara undian (Arikunto, 2002:114). Melalui undian, diperoleh sampel penelitian ini, yaitu kelas VIII.2 SMP Negeri 1 Pagaralam sebanyak 40 siswa.

Kasmadi (2013:61) mengemukakan, metode penelitian adalah prosedural berisi tahapan-tahapan untuk mencapai tujuan dalam bentuk pengorganisasian bahan, strategi penyampaian, dan pengolahan kegiatan suatu penelitian. Menurut Arikunto (2002:126), metode adalah cara untuk mengkaji serangkaian hipotesis menggunakan teknik dan alat-alat tertentu guna mencapai tujuan. Dalam penelitian ini digunakan metode deskriptif dan metode korelasi.

Untuk memperoleh data penelitian ini, penulis menggunakan teknik tes. Menurut Kasmadi (2013:69), tes merupakan rangkaian pertanyaan yang memerlukan jawaban sebagai alat ukur dalam proses asesmen maupun evaluasi dan mempunyai peran penting untuk meng-ukur pengetahuan, 
keterampilan, kecerdasan, bakat, atau kemampuan yang dimiliki individu atau kelompok. Arikunto $(2003: 150)$ mengemukakan, tes adalah serentetan pertanyaan atau latihan yang digunakan untuk mengukur keterampilan, pengetahuan inteligensi, kemampuan atau bakat yang dimiliki oleh individu atau kelompok.

Dalam penelitian ini, penulis menggunakan tes tertulis yang ditujukan kepada siswa sampel dengan bentuk objektif dan esai. Tes menentukan ciri-ciri pantun menggunakan tes esai sebanyak 10 soal. Tes menentukan jenis pantun terdiri atas 10 soal bentuk objektif (pilihan ganda). Tes menulis pantun terdiri atas 10 soal tes bentuk esai.

\section{F. Teknik Analisis Data}

Sesuai dengan teknik pengumpulan data, maka teknik analisis data yang digunakan dalam penelitian ini adalah teknik analisis deskriptif (data tes, data angket, dan data wawancara) dan teknik analisis korelasi.

\section{Teknik Analisis Data Tes}

Analisis data tes dilakukan berdasarkan langkah-langkah sebagai berikut.

1) Data tes memahami ciri-ciri pantun dan kemampuan menentukan jenis pantun dinilai berdasarkan jawaban siswa yang benar dengan bobot masing-masing 10 .
2) Penilaian menentukan ciri-ciri pantun dengan bentuk soal tes esai, skor tes dihitung berdasarkan indeks kesukaran soal (difficulty index), yaitu skor setiap soal didasarkan atas tingkat sukar atau mudahnya soal, yaitu: (1) soal yang tergolong kategori mudah sebanyak 3 soal masing-masing diberi skor 5; (2) soal yang tergolong tingkat kesukaran sedang sebanyak 4 soal masing-masing diberi skor 10; dan (3) soal yang ting-kat kesukarannya tergolong sulit atau sukar sebanyak 3 buah, masing-masing diberi skor 15.

3) Penilaian menentukan jenis pantun dengan bentuk soal tes objektif.

4) Penilaian membuat pantun berpedoman dengan model penilaian menulis dengan pembobotan masing-masing unsur.

\section{Teknik Analisis Korelasi}

Setelah nilai kemampuan memahami ciri-ciri pantun, kemampuan menen-tukan jenis pantun dan kemampuan me-nulis pantun diperoleh, selanjutnya diana-lisis. Ketiga nilai tersebut dikorelasikan berdasarkan langkah-langkah sebagai berikut.

1) Menghitung angka indeks korelasi " $r$ " product moment.

2) Setelah $\underline{r}$ XY diketahui, selanjutnya dinterpretasikan angka indeks korelasi 
"r" product moment berdasarkan pedoman kriteria korelasi.

3) Menyimpulkan ada atau tidaknya hubungan yang signifikan antara pemahaman ciri-ciri pantun dan kemam-puan menentukan jenis pantun dengan kemampuan menulis pantun pada siswa kelas VIII SMP Negeri 1 Pagaralam.

\section{Hasil Penelitian dan Pembahasan}

\section{A. Deskripsi Data}

Data yang dikumpulkan dalam penelitian ini terdiri dari tiga variabel yaitu data tentang kemampuan mema-hami ciri-ciri pantun $\left(\mathrm{X}_{1}\right)$, kemampuan menentukan jenis pantun $\left(\mathrm{X}_{2}\right)$, dan ke-mampuan menulis pantun (Y). Data kemampuan memahami ciri-ciri pantun diperoleh melalui tes esai, data kemam-puan menentukan jenis pantun diperoleh melalui tes objektif, sedangkan data me-nulis pantun diperoleh melalui tes esai menulis pantun.

\section{B. Analisis Data}

\section{Analisis Data Kemampuan}

\section{Memahami Ciri-Ciri Pantun $\left(X_{1}\right)$}

Data kemampuan memahami ciri-ciri pantun diperoleh melalui hasil tes tes esai 10 butir soal yang dilakukan kepada 40 siswa. Hasil tes kemampuan memahami ciri-ciri pantun berdasarkan penilaian dengan rentangan nilai antara 0 dan 100 , diperoleh nilai minimum sebesar 40 dan nilai maksimum sebesar 100

Berdasarkan hasil penilaian, ter-lihat bahwa perolehan skor paling sedikit terdapat pada nilai 40 dan 55 dengan frekuensi sebanyak 2 orang (5\%), sedang-kan perolehan skor paling banyak terda-pat pada nilai 80 dengan frekuensi seba-nyak 8 orang (20\%). Berdasarkan hasil pengolahan data dengan menggunakan SPSS 17.0 for windows diperoleh bahwa nilai modus $(M o)=75$ dan median $(\mathrm{Me})=80$, sedangkan nilai rata-rata $($ mean $)=75,88$ dan simpangan baku $(s)=$ 24,12. Apabila diinterpretasikan maka nilai 75 dan 80 untuk tes kemampuan memahami ciri-ciri pantun pada siswa kelas VIII SMP Negeri 1 Pagaralam meru-pakan nilai terbanyak yang diperoleh siswa.

\section{Analisis Data Kemampuan}

\section{Menentukan Jenis Pantun $\left(\mathbf{X}_{2}\right)$}

Data kemampuan menentukan je-nis pantun pada siswa kelas VIII SMP Negeri 1 Pagaralam yang peroleh mela-lui hasil tes objektif yang dilakukan kepada 45 siswa sampel. Tes kemampuan menentukan jenis pantun sebanyak 10 soal pilihan ganda.

Berdasarkan hasil tes kemampuan menentukan jenis pantun pada siswa kelas VIII SMP Negeri 1 Pagaralam dengan 
rentangan nilai antara 0 dan 100 , diperoleh nilai minimum 45 dan nilai maksimum sebesar 100 .

Berdasarkan hasil perhitungan, terlihat bahwa perolehan skor paling sedikit terdapat pada nilai $45,50,55$, dan 65 , yaitu masing-masing 1 orang (10\%), sedangkan perolehan skor paling banyak terdapat pada nilai 85 dengan frekuensi sebanyak 9 siswa (22,5\%). Berdasarkan hasil pengolahan data dengan meng-gunakan SPSS 17.0 for windows diper-oleh hasil bahwa nilai modus $(M o)=75$ dan median $(M e)=85$, sedangkan nilai rata-rata $($ mean $)=78,5$ dan simpangan baku $(s)=21,5$. Apabila diinterpretasikan maka nilai 85 untuk tes objektif dalam tes kemampuan menentukan jenis pantun pada siswa kelas VIII SMP Negeri 1 Pagaralam merupakan nilai terbanyak yang diperoleh siswa, yaitu 9 orang $(22,5 \%)$.

\section{Analisis Data Kemampuan Menulis}

\section{Pantun (Y)}

Data kemampuan siswa kelas VIII SMP Negeri 1 Pagaralam dalam menulis pantun yang diperoleh melalui hasil tes esai menulis pantun dengan profil penilaian menulis pantun berdasarkan jumlah suku kata setiap baris, jumlah kata setiap baris, sampiran pantun, isi pantun, dan persajakan. Hasil tes menulis pantun dengan 40 siswa sampel berdasarkan penilaian rentangan nilai antara 0--100, diperoleh nilai minimum sebesar 50 dan nilai maksimum sebesar 100 .

Berdasarkan tabel 10, terlihat bah-wa perolehan skor paling sedikit terdapat pada nilai 50 yaitu 1 siswa $(2,5 \%)$, sedangkan perolehan skor paling banyak terdapat pada nilai 85 dengan frekuensi sebanyak masingmasing 8 orang (20\%). Berdasarkan statistik deskriptif dengan menggunakan SPSS 17.0 for windows, diperoleh nilai modus $(M o)=$ 75 dan median $(M e)=85$, sedangkan nilai rata-rata $($ mean $)=76,63$ dan simpangan baku $(s)=12,22$. Bila diinterpretasikan maka skor 85 merupakan skor yang terbanyak yang diperoleh siswa kelas VIII SMP Negeri 1 Pagaralam dalam kemampuan menulis pantun.

\section{Pengujian Persyaratan Analisis}

Pengujian persyaratan analisis perlu dilakukan sebelum data dianalisis lebih lanjut. Pengujian persyaratan ana-lisis yang dilakukan yaitu uji normalitas dan homogenitas. Uji normalitas dilaku-kan karena berdasarkan metode peneli-tian, analisis data dalam penelitian ini menggunakan analisis regresi dan kore-lasi sehingga data variabel bebas maupun variabel terikat harus berdistribusi normal. Sedangkan uji homogenitas dilakukan hanya untuk meyakinkan bahwa variasi skor dari ketiga variabel bersifat homogen. 


\section{a. Normalitas}

Uji statistik Kolmogorov-Smirnov didasarkan pada taraf nyata $(\alpha)=5 \%(0,05)$ dengan kreteria uji, jika proba-bilitas $>0,05$ maka data menyebar secara normal.

\section{a) Koreksi Signifikansi Liliefors}

Kemampuan memahami ciri-ciri pantun, diperoleh signifikansi sebesar = 0,223 lebih besar dari harga alpha $(\alpha=0,05)$. Karena hasil signifikansi $(0,223)$ lebih besar dari harga alpha $(\alpha=0,05)$, maka hipotesis nol diterima, berarti data berdistribusi normal.

\section{b) Koreksi Signifikansi Liliefors}

Kemampuan menentukan jenis pantun, diperoleh signifikansi sebesar $=$ 0,305 lebih besar dari harga alpha $(\alpha=0,05)$. Karena hasil signifikan $(0,305)$ lebih besar dari harga alpha $(\alpha=0,05)$, maka hipotesis nol (Ho) diterima, berarti data berdistribusi normal.

\section{c) Koreksi Signifikansi Liliefors}

Tabel tersebut menunjukan bahwa kemampuan menulis pantun, diperoleh signifikansi sebesar $=0,452$ lebih besar dari harga alpha $(\alpha=0,05)$. Karena hasil signifikan $(0,452)$ lebih besar dari harga alpha $(\alpha=0,05)$, maka hipotesis nol diterima, berarti data berdistribusi normal, karena seluruh data yang digunakan dalam penelitian berasal dari sebaran yang berdistribusi normal dan acak, maka dapat dilakukan uji selanjutnya untuk menguji kebenaran hipotesis penelitian.

\section{b. Homogenitas}

Dasar pengambilan keputusan. Jika $F_{\text {hitung }}<F_{\text {tabel }}$ atau probabilitasnya $>0,05$ maka $H_{0}$ diterima. Jika $F_{\text {hitung }}>F_{\text {tabel }}$ atau probabilitasnya $<0,05$ maka $H_{0}$ ditolak Dengan $\alpha=0,05$ jika nilai Levene's tes signifikan (probabilitas $<0,05)$ maka variansi dari kelompok-kelompok data adalah berbeda dengan hal ini menyalahi asumsi. Jadi yang dike-hendaki adalah hasil Levene's tes tidak signifikan (probabilitas $>$ 0,05). Penghitungan homogenitas menggunakan dengan bantuan program SPSS 17.0 for windows.

Berdasarkan data di atas, dapat dilihat nilai probabilitasnya 0,432 lebih besar dari 0,05, maka $\mathrm{H}_{0}$ diterima, sehingga dapat disimpulkan bahwa data untuk variabel $X_{1}$ (kemampuan mema-hami ciri-ciri pantun) mempunyai variasi yang homogen atau berasal dari data yang homogen, sehingga memenuhi persyaratan pengujian selanjutnya.

Berdasarkan data di atas, dapat dilihat nilai probabilitasnya 0,401 lebih besar dari 0,05, maka $\mathrm{H}_{0}$ diterima, sehingga dapat 
disimpulkan bahwa data untuk variabel $\mathrm{X}_{2}$ (kemampuan menen-tukan jenis pantun) mempunyai variansi yang homogen atau berasal dari data yang homogen, sehingga memenuhi persya-ratan pengujian selanjutnya.

Berdasarkan hasil perhitungan, dapat dilihat bahwa nilai probabilitasnya untuk variabel kemampuan memahami ciri-ciri pantun $\left(\mathrm{X}_{1}\right) \quad 0,432$ dan kemam-puan menentukan jenis pantun $\left(\mathrm{X}_{2}\right)$ 0,401 lebih besar dari 0,05 , maka $\mathrm{H}_{0}$ diterima, sehingga dapat disimpulkan bahwa data untuk variabel $\mathrm{X}_{1}$ dan $\mathrm{X}_{2}$ mempunyai variansi yang homogen atau berasal dari data yang homogen untuk variabel menulis pantun (Y) sehingga memenuhi persyaratan untuk pengujian selanjutnya.

\section{Pembahasan}

\section{Pengujian Hipotesis}

Pengujian hipotesis dilakukan guna mengetahui apakah hipotesis yang diungkapkan dalam penelitian ini dapat diterima atau ditolak. Berdasarkan hasil uji persyaratan, ternyata pengujian hipo-tesis dapat dilakukan sebab sejumlah persyaratan yang ditentukan untuk pengujian hipotesis, seperti normalitas dan homogenitas dari data yang diperoleh dapat dipenuhi.
2. Korelasi Kemampuan Memahami CiriCiri Pantun dengan Kemampuan Menulis Pantun

Berdasarkan hasil perhitungan analisis korelasi sederhana mengenai korelasi atau hubungan kemampuan me-mahami ciriciri pantun $\left(\mathrm{X}_{1}\right)$ dengan kemampuan menulis pantun $(\mathrm{Y})$ diperoleh nilai $\mathrm{r}_{\text {hitung }}=0,981$. Dari hasil analisis tersebut, ternyata indeks korelasi variabel $\mathrm{X}_{1}$ (kemampuan memahami ciri-ciri pantun) dan variabel Y (kemampuan me-nulis pantun) bertanda positif, berarti di antara kedua variabel tersebut terdapat korelasi positif (korelasi yang berjalan searah). Oleh karena $r_{\text {hitung }} \geq r_{\text {tabel }}$ atau $0,981 \geq$ 0,349, maka $\mathrm{H}_{0}$ ditolak yang berarti bahwa kemampuan memahami ciri-ciri pantun memiliki korelasi atau hubungan yang positif dengan kemampuan menulis pantun pada siswa kelas VIII SMP Negeri 1 Pagaralam.

$$
\text { Berdasarkan bukti perhitungan }
$$
tersebut, dapat diinterpretasikan bahwa tinggi rendahnya kemampuan siswa memahami ciri-ciri pantun berkaitan atau berkorelasi erat dengan kemampuan siswa menulis pantun. Dengan demikian, kemampuan siswa dalam menulis pantun dapat dikaitkan dengan kemampuan siswa memahami ciriciri pantun. Hal ini membuktikan bahwa jika siswa mampu memahami ciri-ciri pantun, maka siswa juga mampu menulis pantun. Sebaliknya, jika siswa tidak mampu 
memahami ciri-ciri pantun, maka siswa mengalami kesulitan sehingga siswa tidak atau kurang mampu dalam menulis pantun.

Untuk mengetahui keberartian korelasi, dapat diketahui dengan menggunakan uji "t" yang dilakukan pada taraf signifikansi $5 \%(0,05)$ diperoleh $\mathrm{t}_{\text {hitung }}=$ 32,78. Pada taraf signifikansi $\alpha=0,05$ dan $n$ $=40 \mathrm{t}_{\text {tabel }}=3,32 . \quad$ Uji keberartian menggunakan uji " $\mathrm{t}$ " (dua sisi) diperoleh bahwa $\mathrm{t}_{\text {hitung }} \geq \mathrm{t}_{\text {tabel}}$, oleh karena itu $\mathrm{H}_{0}$ ditolak yang berarti korelasi signifikan. Hal ini menunjukan bahwa hipotesis pertama yang menyatakan "terdapat korelasi yang positif dan signifikan antara kemampuan memahami ciri-ciri pantun dengan kemampuan menulis pantun" terbukti kebenarannya. Oleh karena itu, hipotesis dapat diterima.

Hasil penelitian ini menunjukkan bahwa kemampuan siswa memahami ciri-ciri pantun merupakan salah satu persyaratan untuk meningkatkan kemampuan siswa menulis pantun. Jika dilihat dari hasil pengujian, pola korelasi yang tercipta adalah hubungan positif. Artinya hubungan tersebut merupakan hubungan searah, yang berarti jika kemampuan siswa memahami ciri-ciri pantun baik, maka kemampuan menulis pantun juga menjadi baik dan sebaliknya, jika kemampuan siswa memahami ciri-ciri pantun tidak baik, maka kemampuan menulis pantun juga menjadi tidak baik.
Selanjutnya, guna mengetahui seberapa besar sumbangan dari variabel kemampuan memahami ciri-ciri pantun terhadap kemampuan menulis pantun, maka dicari koefisien diterminasinya. Koefisien diterminasi ditentukan dengan menguadratkan nilai koefisien korelasi-nya dan dikalikan dengan $100 \%$ untuk mendapatkan persentase sumbangannya. Dari tabel 14 diperoleh koefisien korelasi $\left(\mathrm{r}_{\mathrm{YX} 1}\right)=$ 0,973, maka koefisien diterminasi $(\mathrm{KD})=$ $(0,973)^{2}$ x $100 \%=94,67 \%$, sehingga kotribusi kemampuan memahami ciri-ciri pantun terhadap kemampuan menulis pantun besarnya ada-lah 94,67\%. Artinya bahwa 94,67\% variansi nilai kemampuan menulis pantun ditentukan oleh faktor kemampuan me-mahami ciri-ciri pantun.

\section{Korelasi Kemampuan Menentukan} Jenis Pantun dengan Kemampuan Menulis Pantun

Berdasarkan hasil perhitungan analisis korelasi sederhana mengenai korelasi kemampuan menentukan jenis pantun $\left(\mathrm{X}_{2}\right)$ dengan kemampuan menulis pantun (Y) diperoleh nilai $r_{\text {hitung }}=0,968$. Dari hasil analisis tersebut, ternyata indeks korelasi variabel $\mathrm{X}_{2}$ (kemampuan menentukan jenis pantun) dan variabel Y (kemampuan menulis pantun) bertanda positif, berarti di antara kedua variabel tersebut terdapat korelasi yang positif (korelasi yang berjalan searah). 
Oleh karena $r_{\text {hitung }} \geq r_{\text {tabel }}$ atau $0,968 \geq 0,349$ maka $\mathrm{H}_{0}$ ditolak yang berarti bahwa kemampuan menentukan jenis pantun berhubungan dengan kemampuan menulis pantun pada siswa kelas VIII SMP Negeri 1 Pagaralam sehingga hipotesis teruji (terdapat hubungan yang positif antara kemampuan menentukan jenis pantun dengan kemampuan menulis pantun).

Untuk mengetahui keberartian korelasi, dapat diketahui dengan menggunakan uji "t" yang dilakukan pada taraf signifikansi $5 \%(0,05)$ diperoleh $t_{\text {hitung }}=$ 21,79. Pada taraf signifikansi $\alpha=0,05$ dan $n$ $=40 \mathrm{t}_{\text {tabel }}=2,32 . \quad$ Uji keberartian menggunakan uji "t" (dua sisi) sehingga $t_{\text {hitung }} \geq \mathrm{t}_{\text {tabel }}$ atau $21,79 \geq 2,32$ yang berarti korelasi signifikan. Hal ini menunjukan bahwa hipotesis kedua yang menyatakan "terdapat korelasi yang signifikan antara kemampuan menentukan jenis pantun dengan kemampuan menulis pantun" dapat diterima.

Hasil penelitian ini menunjukan bahwa kemampuan siswa menentukan jenis pantun merupakan salah satu syarat yang penting dalam meningkatkan kemampuan siswa dalam menulis pantun. Jika dilihat dari hasil pengujian yang ada, pola hubungan yang tercipta adalah positif. Artinya hubungan tersebut meru-pakan hubungan searah, yang berarti apabila kemampuan menentukan jenis pantun baik, maka kemampuan menulis pantun juga menjadi baik, sebaliknya apabila kemam-puan menentukan jenis pantun tidak baik, maka kemampuan siswa dalam menulis pantun juga menjadi tidak baik.

Selanjutnya, guna mengetahui besarnya sumbangan atau kontribusi dari variabel kemampuan menentukan jenis pantun terhadap kemampuan siswa me-nulis pantun, maka dicari koefisien diterminasinya. Koefisien diterminasi ini ditentukan dengan menguadratkan nilai koefisien korelasinya dan dikalikan dengan 100\% untuk mendapatkan persentase sumbangannya. Dari tabel 22 diperoleh koefisien korelasi $\left(\mathrm{r}_{\mathrm{YX} 2}\right)=$ 0,968, maka koefisien diterminasi $(\mathrm{KD})=$ $(0,968)^{2}$ x $100 \%=93,70 \%$, sehingga kotribusi kemampuan menentukan jenis pantun terhadap kemampuan menulis pantun besarnya adalah sebesar 93,70\%. Artinya bahwa 93,70\% variansi nilai kemampuan menulis pantun pada siswa kelas VIII SMP Negeri 1 Pagaralam ditentukan faktor kemampuan menentukan jenis pantun, yaitu sebesar $93,70 \%$.

\section{Korelasi Kemampuan Memahami} Ciri-Ciri Pantun dan Kemampuan Menentukan Jenis Pantun dengan Kemampuan Menulis Pantun

Berdasarkan hasil perhitungan tersebut, diperoleh nilai $r_{\text {hitung }}=2,172$. Dari hasil analisis, ternyata indeks korelasi $\mathrm{X}_{1}$ (kemampuan memahami ciri-ciri pantun) dan $\mathrm{X}_{2}$ (kemampuan menentukan jenis pantun) dengan variabel $\mathrm{Y}$ (kemampuan menulis 
pantun) bertanda positif, berarti di antara ketiga variabel tersebut terdapat korelasi positif (korelasi searah). Hal ini berarti bahwa kemampuan memahami ciri-ciri pantun dan kemampuan menen-tukan jenis pantun berkorelasi (berhu-bungan) dengan kemampuan menulis pantun pada siswa kelas VIII SMP Negeri 1 Pagaralam sehingga hipotesis teruji "terdapat hubungan yang positif dan signifikan dari kemampuan memahami ciri-ciri pantun dan kemampuan menentukan jenis pantun dengan kemampuan menulis pantun siswa kelas VIII SMP Negeri 1 Pagaralam". Dengan demikian, hipotesis terbukti kebenarannya. Oleh karena itu, hipotesis diterima.

Hal ini berarti, tinggi rendahnya kemampuan siswa memahami ciri-ciri pantun dan kemampuan menentukan jenis pantun berkaitan dengan kemampuan menulis pantun. Dengan demikian, kemampuan siswa menulis pantun dapat dikaitkan dengan kemampuan memahami ciri-ciri pantun dan kemampuan menentukan jenis pantun. Dengan demikian, dapat dinyatakan bahwa agar siswa mampu menulis pantun secara benar, maka siswa harus terlebih dahulu memiliki kemampuan memahami ciri-ciri pantun dan harus mampu menentukan jenis pantun. Dengan kemampuan memahami ciriciri pantun dan kemampuan menentukan jenis pantun, siswa mampu menulis pantun secara benar sesuai dengan ciri-ciri dan jenis pantun yang ditulisnya.

Berdasarkan

perhitungan

menggunakan taraf signifikansi 5\% $(0,05)$ diper-oleh $F_{\text {tabel }}=3,30$. Karena $F_{\text {hitung }}>F_{\text {tabel }}$ atau 23,49 $>3,30$ sehingga $\mathrm{H}_{0}$ ditolak. Hal ini menunjukan bahwa hipotesis ketiga yang menyatakan bahwa "terdapat korelasi positif dan signifikan antara ke-mampuan memahami ciri-ciri pantun dan kemampuan menentukan jenis pantun de-ngan kemampuan menulis pantun" ter-bukti kebenarannya. Oleh karena itu, hipotesis dapat diterima.

Hasil penelitian ini menunjukan bahwa kemampuan siswa memahami ciri-ciri pantun dan kemampuan menentukan jenis pantun merupakan salah satu persyaratan dalam keberhasilan siswa menulis pantun. Jika dilihat dari hasil pengujian yang ada, pola hubungan yang tercipta adalah positif. Artinya hubungan tersebut merupakan hubungan yang searah, yaitu apabila siswa mampu memahami ciri-ciri pantun dan mampu menentukan jenis pantun, maka siswa juga mampu menulis pantun dengan benar dan sebaliknya, jika siswa tidak mampu memahami ciri-ciri pantun dan tidak mampu menentukan jenis pantun, maka siswa juga mengalami kesulitan menulis pantun dan mengakibatkan siswa tidak mampu menulis pantun secara benar. 
Setelah signifikansi korelasi terpenuhi, maka langkah selanjutnya adalah menghitung koefisien diterminasi. Dari hasil perhitungan berdasarkan tabel 22, diperoleh harga koefisien korelasi $\mathrm{R}_{\mathrm{YX} 1 \mathrm{X} 2}$ sebesar 0,40 sehingga $\mathrm{KD}=(0,968)^{2} \times 100 \%=93,70 \%$. Hal ini menunjukan bahwa kontribusi kemampuan memahami ciri-ciri pantun dan kemampuan menentukan jenis pantun terhadap kemampuan menulis pantun besarnya adalah 93,70\%. Artinya, bahwa $93,70 \%$ variansi nilai kemampuan menulis pantun dipengaruhi atau ditentukan oleh faktor kemampuan memahami ciri-ciri pantun dan kemampuan menentukan jenis pantun.

Hasil penelitian menunjukan bahwa kemampuan siswa dalam menulis pantun dipengaruhi kemampuan memahami ciri-ciri pantun dan kemampuan menentukan jenis pantun. Faktor-faktor lain yang berkorelasi dan mempengaruhi kemapuan menulis pantun selain dari kemampuan memahami ciri-ciri pantun dan kemampuan menentukan jenis pantun di antaranya adalah faktor intern, yaitu tingkat inteligensi (kecerdasan) siswa dan minat atau kemauan siswa mempelajari pantun dan faktor ekstern, yaitu motivasi belajar, baik dari guru maupun dari keluarga dan faktor metode pembelajaran yang digunakan oleh guru dalam pembelajaran menulis pantun. Dengan de-mikian, selain faktor kemampuan mema-hami ciriciri pantun dan kemampuan menentukan jenis pantun, maka faktor-faktor intern dan ekstern juga berperan mempengaruhi kemampuan siswa dalam menulis pantun. Oleh karena itu, faktor intern dan ekstern perlu diperhatikan guna memperoleh hasil pembelajaran menulis pantun yang lebih baik, khususnya pada siswa kelas VIII SMP Negeri 1 Pagaralam.

\section{SIMPULAN, IMPLIKASI, SARAN}

\section{A. Simpulan}

Berdasarkan hasil analisis data dan pembahasan diperoleh simpulan dari penelitian ini sebagai berikut.

1. Terdapat korelasi yang signifikan anta-ra kemampuan memahami ciri-ciri pantun dengan kemampuan menulis pantun siswa kelas VIII SMP Negeri 1 Pagaralam.

2. Terdapat korelasi yang signifikan antara kemampuan menentukan jenis pan-tun dengan kemampuan menulis pan-tun siswa kelas VIII SMP Negeri 1 Pagaralam.

3. Terdapat korelasi yang signifikan antara kemampuan memahami ciri-ciri pantun dan kemampuan menentukan jenis pantun dengan kemampuan me-nulis pantun siswa kelas VIII SMP Negeri 1 Pagaralam 


\section{B. Implikasi}

Penelitian hubungan kemampuan memahami ciri-ciri pantun dan menentukan jenis pantun dengan kemampuan menulis pantun siswa kelas VIII SMP Negeri 1 Pagaralam, dapat menimbulkan implikasi, baik implikasi teoretis, implikasi akademis, maupun implikasi praktis.

Implikasi teoretis berkaitan dengan manfaat penelitian secara teoretis bagi pengajaran puisi dan bahan pelengkap tentang teori-teori pantun serta menjadi acuan untuk melakukan penelitian lanjutan mengenai pengajaran pantun. Implikasi akademis merujuk pada upaya menumbuhkan dan memotivasi minat siswa mempelajari ciri-ciri, jenis, dan penulisan pantun sehingga kemam-puan siswa dalam menulis pantun dapat ditingkatkan sesuai dengan tujuan kuri-kulum. Penelitian tentang hubungan kemampuan memahami ciri-ciri pantun dan menentukan jenis pantun dengan kemampuan menulis pantun dapat digunakan sebagai salah satu alternatif untuk meningkatkan kemampuan menulis pantun sehingga siswa tidak hanya menjadi pembaca pantun yang telah ada, tetapi juga mampu menulis pantun sebagai karya siswa sendiri. Penelitian tentang hubungan kemampuan memahami ciri-ciri pan-tun dan kemampuan menentukan jenis pantun dengan kemampuan menulis pantun berimplikasi dalam memotivasi dan melatih keterampilan siswa agar mampu mengungkapkan isi hati atau perasaan melalui pantun ciptaannya sendiri.

Implikasi praktis berhubungan dengan pembelajaran Bahasa Indonesia, khususnya kompetensi dasar menulis pantun, penelitian ini kiranya dapat mem-bangkitkan kembali minat siswa untuk mempelajari pantun dan manfaatnya serta menanamkan apresiasi siswa terhadap pantun sehingga pantun sebagai hasil karya sastra lama yang merupakan hasil karya sastra asli nusantara dapat dilestarikan.

\section{Saran}

Setelah menyimpulkan hasil penelitian ini, penulis mengemukakan saransaran sebagai berikut.

1) Guru Bahasa Indonesia yang mengajar di kelas VIII SMP Negeri 1 Pagaralam hendaknya menggunakan hasil penelitian ini sebagai acuan peleng-kap materi pembelajaran untuk meng-ajarkan penulisan pantun.

2) Guru hendaknya memotivasi minat siswa untuk mempelajari materi pem-belajaran penulisan pantun sehingga hasil pembelajaran dapat lebih baik.

3) Bagi peneliti selanjutnya, hendaknya meneliti tentang pengajaran yang berhubungan dengan pembelajaran sas-tra, misalnya menggunakan metode 
penelitian deskriptif-analitis, analisis pengembangan, dan lain-lain.

\section{Daftar Pustaka}

Ambary, Abdullah. 2005. Intisari Sastra Indonesia. Bandung: Djatnika.

Arikunto, Suharsimi. 2002. Prosedur Penelitian Suatu Pendekatan Praktik. Jakarta : Rineka Cipta.

Arikunto, Suharsimi. 2003. Dasar-Dasar Evaluasi Pendidikan. Jakarta: Bumi Aksara.

Budiman, Sumiati. 2007. Sari Sastra Indonesia. Surakarta: Intan Pariwara.

Djajadisastra, Jusuf. 2006. Bahasa Indonesia, Sastra. Bandung: PPPG Tertulis.

Luxemburg, Jan van. 2008. Pengantar Ilmu Sastra. Jakarta: Gramedia.

Mihardja, Ratih. 2013. Buku Pintar Sas-tra Indonesia. Jakarta: Laskar Aksara.

Moeliono, Anton M., dkk. 2007. Kamus Besar Bahasa Indonesia. Jakar-ta: Perum Balai Pustaka.

Nagara, Aditya. 2002. Kamus Praktis Bahasa Indonesia. Surabaya: Bintang Usaha Jaya.

Nurgiyantoro, Burhan. 1995. Penilaian dalam Pengajaran Bahasa dan Sastra Indonesia. Yogyakarta: BPFE.

Riyanto, Yatim. 2010. Metodologi Penelitian Pendidikan. Surabaya: SIC.
Sayuti, A. 2012. Puisi dan Peng-ajarannya (Sebuah Pengantar). Semarang: IKIP Semarang Press.

Sudaryat, Ndang. 2006. Ringkasan Baha-sa Indonesia. Bandung: Ganeca Exact.

Sudijono, Anas. 2006. Pengantar Statistik Pendidikan. Jakarta: Rajawali Pers.

Sugiarto, Eko. 2013. Cara Mudah Menu-lis Pantun, Puisi, Cerpen. Yog-yakarta: Khitah Publishing.

Sugiyomo. 2010. Metode Penelitian Pendidikan Pendekatan Kuantitatif, Kualitatif, dan $R \& D$. Bandung: Alfabeta.

Suharianto, S. 1992. Dasar-Dasar Teori Sastra. Surakarta: Sinar Baru.

Sukardi. 2003. Metodologi Penelitian Pendidikan. Jakarta: Bumi Aksa-ra.

Sumardjo, Jacob dan Saini, K. M. 2008. Apresiasi Kesusastraan. Jakarta: Gramedia.

Tarigan, Henry Guntur. 2004. PrinsipPrinsip Dasar Sastra. Bandung: Angkasa.

Utami. 2013. Pintar Pantun, Puisi, Peribahasa, dan Majas. Yogyakarta: Naafi' Media.

Wardiah. 2011. "Korelasi antara Kemampuan Menentukan Isi Pantun dan Kemampuan Menentukan Makna Pantun dengan Kemampuan Me-nulis Pantun Siswa Kelas VIII SMP Negeri 2 Bukit Tinggi" Tesis (tidak diterbitkan). Padang: PPs. Universitas Negeri Padang 